\title{
Differences in home range, activity patterns and diet of red howler monkeys in a continuous forest and a forest fragment in Colombia
}

\author{
Pablo R. Stevenson ${ }^{1, *}$, Marta L. Beltrán ${ }^{1}$, Marcela J. Quiñones ${ }^{1,2}$, Jorge A. Ahumada ${ }^{1,3}$ \\ ${ }^{1}$ Centro de Investigaciones Ecológicas La Macarena. Departamento de Ciencias Biológicas, Universidad de Los Andes. Bogotá, Colombia \\ ${ }^{2}$ Department of Environmental Sciences, Wageningen University, Wageningen, The Netherlands \\ ${ }^{3}$ Tropical Ecology Assessment and Monitoring Network (TEAM), Center for Applied Biodiversity Science, \\ Conservation International. Arlington, VA, USA
}

\begin{abstract}
Howler monkeys, genus Alouatta, are recognized as one of the most resistant primates to forest fragmentation. In this study a comparison of the home range, activity and diet of red howler monkeys (A. seniculus) was made between a continuous forest and a fragment in Meta, Colombia (Tinigua Park and Santa Rosa farm, respectively). Data was gathered on focal animals for 4-5 days per month, over 13 months in the continuous forest, and for six months in a 21-ha fragment. Home range areas were larger in the continuous forest. Resting was the most frequent activity in both places (58-59\%), but individuals in the continuous forest moved more than those in the fragment (15 vs. 9\%). In contrast, feeding was less frequent in the continuous forest (23 vs. 31\%). Consumption of leaves was higher in the fragment (67\%) than in the continuous forest (56\%), contrasting with the pattern found for ripe fruit consumption (fragment: 32\%, continuous forest: 44\%). Results from phenological transects indicate that fruits were consumed in proportion to their abundance; however, the same was not true for young leaves. Due to increased production and tree species diversity, the number of fruit species consumed in the continuous forest was greater than in the fragment. No differences were found in feeding rates among group members, suggesting an egalitarian society in terms of resource acquisition. Results from this study show that fragmentation affects home range, moving patterns, and diet composition. Overall, the dietary and behavioral flexibility shown by howler monkeys allow them to live in fragments, and it is suggested that this is more likely in areas with high productivity and few competitors.
\end{abstract}

Key words: Alouatta seniculus, ecological traits, feeding strategies, group size, Tinigua National Park.

Diferencias en el rango de hogar, el patrón de actividades y la dieta de monos aulladores rojos en bosque continuo y en un fragmento de bosque en Colombia

\section{Resumen}

Los aulladores, género Alouatta, son reconocidos como los primates más resistentes a la fragmentación de bosques. En este estudio se comparan el rango de hogar, actividad y dieta de los aulladores rojos (A. seniculus) en bosque continuo y en un fragmento en el Meta, Colombia (Parque Nacional Tinigua y finca Santa Rosa, respectivamente). Se registró información con observaciones focales durante 4-5 días por mes (13 meses en el bosque continuo y 6 en un fragmento de 21-ha). El rango de hogar fue mayor en el bosque continuo. El descanso fue la actividad preponderante en ambos lugares (58-59\%), pero el movimiento fue más frecuente en bosque continuo que en el fragmento (15\% vs. 9\%), contrario a lo encontrado para alimentación (23 vs. 31\%). La proporción de hojas en la dieta fue mayor en el fragmento (67\%) que en el bosque continuo (56\%), y el patrón opuesto se registró para el consumo de frutos (fragmento: 32\%, bosque continuo: 44\%). De acuerdo a muestreos fenológicos, los frutos fueron consumidos en proporción a su abundancia, y esto no ocurrió para el consumo de hojas. Debido a la mayor productividad y diversidad en el bosque continuo, el número de especies consumidas fue mayor en el bosque continuo que en el fragmento. No se encontraron diferencias en las tasas de alimentación entre miembros del grupo, sugiriendo una sociedad igualitaria, en términos de adquisición de recursos. Se concluye que la fragmentación está asociada a cambios en el rango de hogar, patrones de movimiento y dieta de los monos aulladores. En general esta flexibilidad en dieta y comportamiento de estos primates facilita que ocurran en bosques perturbados y se sugiere que esto va a ser más probable en lugares productivos y con pocos competidores.

Palabras clave: Alouatta seniculus, estrategias alimenticias, ecología de primates, Parque Nacional Natural Tinigua, tamaño de grupo. 


\section{Introduction}

Forest fragmentation reduces plant diversity, changes the composition of plant communities, and may affect the type of resources available for herbivores (Saunders, et al., 1991; Laurance, et al., 2002; Hobbs \& Yates, 2003; Stevenson \& Aldana, 2008). Therefore, the social organization and the ecological strategies of animals living in such habitats must be flexible enough to enable them to survive with limited resources (Crockett, 1998). Despite their large body size, howler monkeys are often found in small fragments. This study examines socio-ecological traits of red howler monkeys (Alouatta seniculus) in a continuous and a fragmented forest located in the same region (Crockett, 1996; Clarke, et al., 2002), providing ideas on how these primates manage to survive in disturbed habitats, and how their behavior changes in relation to habitat fragmentation (Bicca-Marques, 2003).

Red howler monkeys live in small groups, ranging between 3 and 16 individuals (mean $7.9 \pm 1.4$ ) (Di Fiore \& Campbell, 2007) that contain several adult females, their offspring and one or a few adult males (usually only one reproducing) (Pope, 1990). Infanticide is common following a change in the dominant male (Crockett, 2003), and there is high body size dimorphism (females: 4.5-6.0 kg and males: 6.5$8.0 \mathrm{~kg}$, Thorington, et al., 1979). In general resting is their main diurnal activity and social interactions are infrequent (Gaulin \& Gaulin, 1982; Wang \& Milton, 2003, Palma, et al., 2011), but intergroup vocal encounters are common at home range boundaries (Sekulic, 1982). Individuals of both sexes are known to disperse from natal groups (Pope, 1992; Agoramoorthy \& Rudran, 1993; Rudran \& FernandezDuque, 2003).

The diet of red howler monkeys includes predominantly leaves and fruits, but they also consume seeds, soil, flowers and termite nest material (Di Fiore \& Campbell, 2007). They prefer fruits over leaves in periods of fruit abundance and disperse seeds of many fruit species (Julliot, 1996; Andresen, 1999; Stevenson, et al., 2002; Santamaría, 2004). Seed shadows generated by howler monkeys depend mainly on their ranging patterns. Home range size may be reduced in fragmented habitats (Santamaría, 2004). In periods of fruit shortage they may rely exclusively on leaves, a resource that is available all year long, and young leaves are preferred over mature leaves (Julliot \& Sabatier, 1993; Santamaría \& Rylands, 2003). Howler monkeys are the most folivorous primates in the Neotropics, and the high proportion of leaves in their diet has been proposed as the cause of the high level of resting in their daily activities (Milton, 1998).

\footnotetext{
*Corresponding author:

Pablo R. Stevenson, pstevens@uniandes.edu.co

Recibido: 9 de julio de 2015

Aceptado: 20 de octubre de 2015
}

Even though howler monkeys are one of the most studied primates in the Neotropics, there is still no full understanding of the factors determining their population density dynamics (Peres, 1997; Chapman \& Balcomb, 1998). Howler populations may decrease due to predation, diseases and infanticide (Izawa, 1997). It has been reported that howler monkeys can be predated by large eagles and felids (Treves, et al., 2001; Miranda, et al., 2005). However, the most pronounced variations in population densities seem to be related to diseases, such as yellow fever (Sallis, et al., 2003). It has also been suggested that infanticide might limit the population growth of some primate species in such a way that they are not limited from dietary resources (Sterck, et al., 1997).

The main aim of this study was to describe the home range, activity, diet, and social behaviors of two red howler populations, one in a pristine environment and one in a small fragment, both located in the same region. A description of these social and ecological traits using standard methods, should allow a better understanding of their habitat requirements, and of the way they respond to anthropogenic disturbance such as forest fragmentation. In addition, two hypotheses related to group size and agonistic interactions were tested. It was predicted that average group size should be larger in continuous forests than in fragments, since the latter have a high mortality of large trees (Laurance, et al., 2002), and competition for resources might also be high (Terborgh \& Janson, 1986). In addition, fragments were predicted to have low productivity, possibly causing an increase in aggressive behaviors due to higher competition for resources (Isbell, 1991; Isbell \& van Vuren, 1996).

\section{Methods}

\section{Study Sites}

The undisturbed study site is located in a tropical lowland forest on the eastern border of Tinigua National Park (201,875 ha), west of Sierra de La Macarena, Departamento del Meta, Colombia, ( $2^{\circ} 40^{\prime} \mathrm{N}, 74^{\circ} 10^{\prime} \mathrm{W}$; 350-400 m). At the time of the study, the region had not suffered significant habitat disturbance. Terra firme and flooded forests are the main forest types (Stevenson, et al., 2004). Mean annual rainfall is of 2,791 mm, and 2-3 dry months occur between January and March (Stevenson, et al., 2008). Seven primate species are present in the area, woolly monkeys (Lagothrix lagothricha lugens) (41-50 ind. $/ \mathrm{km}^{2}$ ) the most abundant species, brown capuchins (Sapajus apella) (24-31 ind./ $/ \mathrm{km}^{2}$ ), spider monkeys (Ateles belzebuth) (23-25 ind. $\left./ \mathrm{km}^{2}\right)$, red howlers (Alouatta seniculus) (17-30 ind./km²), and squirrel monkeys (Saimiri sciureus) (9-16 ind./km²) (Stevenson, 2007). Titi monkeys (Callicebus ornatus) are present at low population densities and there are no available estimates for night monkeys (Aotus cf. brumbacki).

The fragment is located in the Santa Rosa farm (03³6'27'N, 73³8'13”W; $362 \mathrm{~m}$ a.s.l.), in the municipality of San Martín, Meta, 100 km north of Tinigua Park. Santa Rosa is 
used for cattle ranching and there are forest fragments along the Caracoles stream, which is used as a water supply. The study fragment has 21 ha and is considered as high terrace that floods for only a few days every year (Carretero, 2008). Annual rainfall during the study year was of 2,581 mm (Carretero, 2008), with two dry months (January and December with less than $100 \mathrm{~mm}$ ). There is active wood extraction inside the forest for different uses. Five primate species inhabit the fragment, and estimates of the diurnal species (Torres-Neira, 2005), indicate relatively high population densities (A. seniculus: 144 ind. $/ \mathrm{km}^{2}, C$. ornatus: 119 ind. $/ \mathrm{km}^{2}$, S. sciureus: 125 ind. $/ \mathrm{km}^{2}$, and $S$. apella: 75 ind. $\left./ \mathrm{km}^{2}\right)$.

\section{Data Collection}

Data on habitat use, activity, and diet were collected over 13 months (March 1990-March 1991), using a combination of focal animal methods and instantaneous samplings in Tinigua Park. Activity and diet were quantified using instantaneous samples every 10-min, and for habitat use, 30min intervals were used (Stevenson, et al., 2000). Time spent by individuals feeding on different food types was recorded continuously during focal samples. Each age/sex class was sampled for one day, during the four days of data collection per month per group. Four different age/sex classes were sampled (adult males, lactating females, non-lactating adult females, and immature individuals-juveniles and subadults of both sexes). In the fragment, data were gathered for 5 days per month, from March to August 2004, using the same method used in continuous forest. All group members were individually identified using facial traits, sex and body size. Activities were classified as moving, resting, feeding, or social interactions (mainly play and agonistic encounters since grooming was uncommon). Food items were classified as fruits (ripe and unripe), seeds, leaves (young and mature), flowers, and other items (e.g., termite nest).
Several habituated groups were observed both in the continuous forests and the fragment; however, behavioral data were gathered from a single group at each site (MN-4 and MB-M, Table 1). Home range size was estimated using the $100 \%$ minimum convex polygon method. However, the home range of the MN-4 group (continuous forest) was $\mathrm{L}$ shaped and, therefore, it was measured as the sum of two independent polygons. In addition, the home range and group sizes of other groups present in Tinigua Park were obtained from published studies (Izawa \& Lozano, 1992; Kimura, 1992; Izawa, 1997) (Table 1).

Fruit production was quantified using phenological transects, which were monitored twice a month during the study period. The length of transects was $5.6 \mathrm{~km}$ in the continuous forest $(\mathrm{N}=12)$ and $3.7 \mathrm{~km}$ in the fragment $(\mathrm{N}=2)$. Fruit production was calculated using the same protocol used by Stevenson and Link (2010), including an assessment of crop size for each fruiting plant located along transects, fruit weight, and an estimation of transect width (based on perpendicular distance from the transect to the trunk). The fruit production estimated for each tree was then added up and calculated over an area (transect length and effective width, which varies depending on plant size). Fruit feeding preferences were assessed based on the residuals of the relationship between fruit abundance (kg/ha in transects) and fruit consumption (feeding time of focal animals in minutes) (Stevenson \& Link, 2010). In order to assess the abundance of new leaves, five marked individuals of plant species commonly used by primates were monitored (24 species in the continuous forest and five in the fragment). Although the selection of these species was determined a priori, the list included the majority of plants heavily consumed by howler monkeys (e.g. Brosimum spp., Ficus spp., Protium spp., Cecropia spp.).

Table 1. Information on group size, home range and composition of the red howler monkey groups studied in continuous forest in Tinigua National Park and a fragment in Santa Rosa farm, Meta (Colombia).

\begin{tabular}{|c|c|c|c|c|c|c|c|c|}
\hline Site & Santa Rosa & Santa Rosa & Santa Rosa & Tinigua & Tinigua & Tinigua & Tinigua & Tinigua \\
\hline Group & MB-M ${ }^{1}$ & MB-C ${ }^{1}$ & MB-L ${ }^{1}$ & $\mathrm{MN}-1^{2,3}$ & $\mathrm{MN}-2^{4}$ & $\mathrm{MN}-3^{1}$ & $\mathrm{MN}-4^{1}$ & MN-D ${ }^{1}$ \\
\hline Mean Size & 6.5 & 6.0 & 8.0 & 7.0 & 12.7 & 8 & 11.0 & 8.0 \\
\hline Adult males & $3-2$ & & & $0-3$ & 1 & 2 & $3-1$ & 2 \\
\hline Adult females & 2 & & & 2 & 4 & 2 & 4 & 2 \\
\hline Subadult males & & & & $0-1$ & & 1 & 1 & 1 \\
\hline \multicolumn{9}{|l|}{ Subadult females } \\
\hline Juveniles & 1 & & & 2 & 4 & 2 & 2 & 2 \\
\hline Infants & 1 & & & $0-2$ & 4 & 1 & $1-3$ & 1 \\
\hline Home range (ha) & 12 & 12 & 16 & 32 & 24 & 75 & 79 & 82 \\
\hline Area / monkey & 1.85 & 2.00 & 2.00 & 4.85 & 1.89 & 9.38 & 7.18 & 6.25 \\
\hline
\end{tabular}

${ }^{1}$ Personal observations; ${ }^{2}$ Izawa \& Lozano 1992; ${ }^{3}$ Izawa 1997; ${ }^{4}$ Kimura 1992 


\section{Data Analyses}

Median and Student's t tests were used to compare home range size, group size, and the rate of vocal encounters between continuous and fragmented forests, using Jump software. One-tailed tests were used based on the predictions, and statistical significance was set at $p=0.05$. G-tests of independence were used to look for associations between forest type, activity budgets and diet, and also between activity patterns and months. Correlation and regression analyses were used to assess the effect of resource abundance on activity and diet. ANOVA tests were used to compare feeding times among group members.

\section{Results}

\section{Home range and group size}

The home range size of the MN-4 group (continuous forest) was estimated to be 79 ha, and 12 ha for the MB-N group (forest fragment). During the first six months, the home range of the group in the continuous forest was 46 ha, about four times the area used by the group in the fragment during a similar period of time. Even when controlling for group size, home range size was still larger in the continuous forest (continuous: 7.2 ha/ind. vs. fragment: 1.9 ha/ind.; $\mathrm{Chi}^{2}=$ 4.2, $P=0.04)$.). When including published and unpublished information from 5 groups in the continuous forest, and from 3 in the fragment (Table 1), it was clear that the variation in home range area was larger in the continuous forest and, on average, home ranges were also larger (median test: $\mathrm{Chi}^{2}=$ $4.2, P=0.04$ ). Average group size tended to be higher in the continuous forest $(9.3 \pm 0.9$ vs. $6.8 \pm 1.2 \mathrm{SE}$ in the fragment), but the analysis did not show a significant difference ( $\mathrm{T}$ test: $t=2.1, P=0.09$ ).

\section{Activity patterns}

A significant association was found between activity budgets and sites $(\mathrm{G}=84, \mathrm{df}=3, \mathrm{p}<0.001)$. Resting was the predominant activity in both forest types, leading to similar instantaneous records (58 vs. 59\%). Overall, the main differences between sites were due to a higher frequency of movement in the continuous forests $(15 \%$ vs. $9 \%$ in the fragment, $n=3120$ and 1800 , respectively), contrary to the pattern found for feeding (23 vs. 31\%). Social interactions were infrequent in both populations (3\% in continuous forests and $1 \%$ in the fragment) (Figure 1.a).

In both populations, resting was the predominant activity during the morning and midday hours, and feeding peaked in the afternoon (15:00-16:00 h) (Figure 2). Differences in activity patterns were found among months for both populations (Continuous forest: $\mathrm{G}=162.5, \mathrm{df}=26, \mathrm{p}<0.001$; Fragment: $\mathrm{G}=24.8, \mathrm{df}=10, \mathrm{p}=0.002$ ); however, these variations did not show any clear seasonal patterns (Figure 3).

There were no associations between age/sex classes (or individuals) and activity budgets for the group in the fragment $(G=8.44, p=0.40)$. However, the group in the
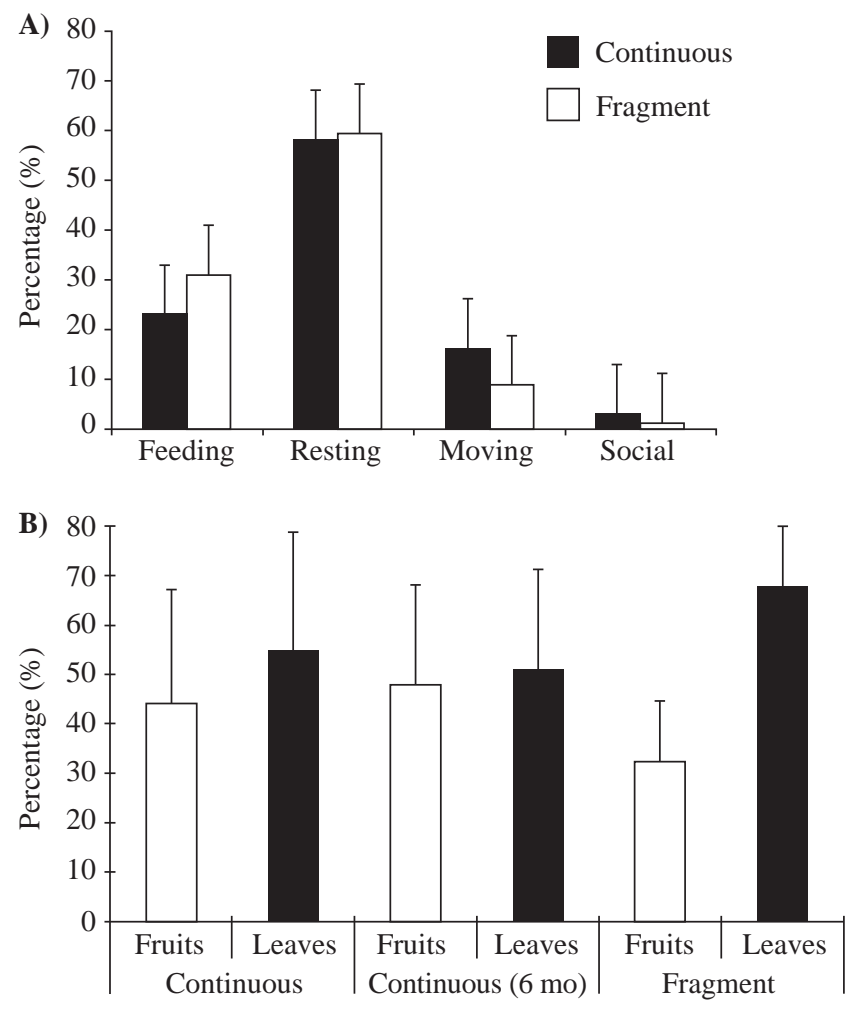

Figure 1. Comparison of activity patterns and diet or red howler monkeys living in continuous and fragmented forests in Meta Department, Colombia. A) The frequency of instantaneous records in different activities, and B) main diet categories. The standard deviation from monthly estimates is shown over the bars.

continuous forest did show associations between these variables ( $G=64.7$, $\mathrm{df}=9, p<0.001)$. The main differences were found for juveniles (more common in the continuous forest group), as they spent more time in social interactions (i.e., playing) and less time resting.

Only 6 intra-group agonistic interactions (i.e. chases, bites) were recorded during the study in the continuous forest (0.010 per hour). Four of them were by adults towards juveniles, but one aggression between two adult males, and one by an adult male towards an adult female were also observed. Seventeen agonistic interactions were registered for the group in the fragment ( 0.047 per hour), all of them between adult males, except for a male-female aggression, including an infanticide (Beltran and Stevenson, 2013). In fact, based on access to females and severe wounds, during the six-month study period, three changes of dominant male were observed. However, both males remained in the group throughout the study. Feeding time was not associated with dominance status between adult males $(G=0.03, \mathrm{df}=5, p=$ 0.86 ). In spite of the high number of howler monkey groups in the fragment, there were no differences in the frequency of intergroup vocal encounters between the two groups (median of 6.9 per month in continuous forest and 6.0 per month in the fragment) (median test: $C h i^{2}=4.01, p=0.05$ ). 


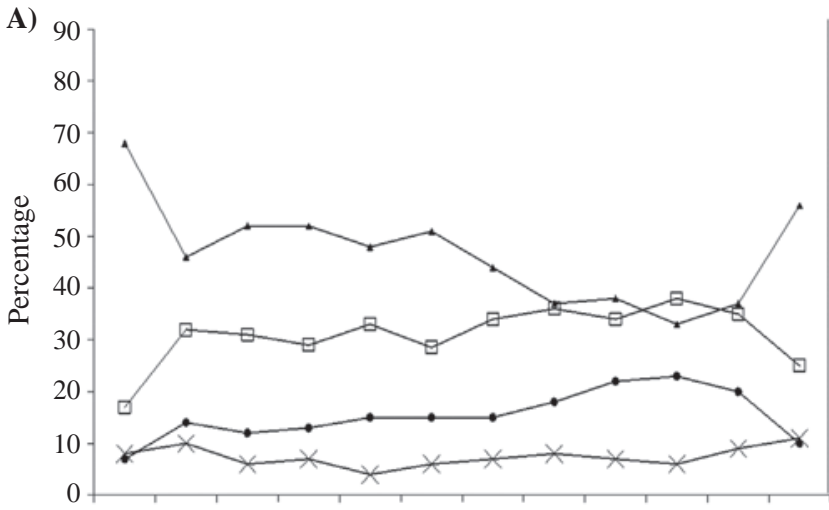

6:00 7:00 8:00 9:00 10:00 11:0012:00 13:00 14:00 15:00 16:00 17:00

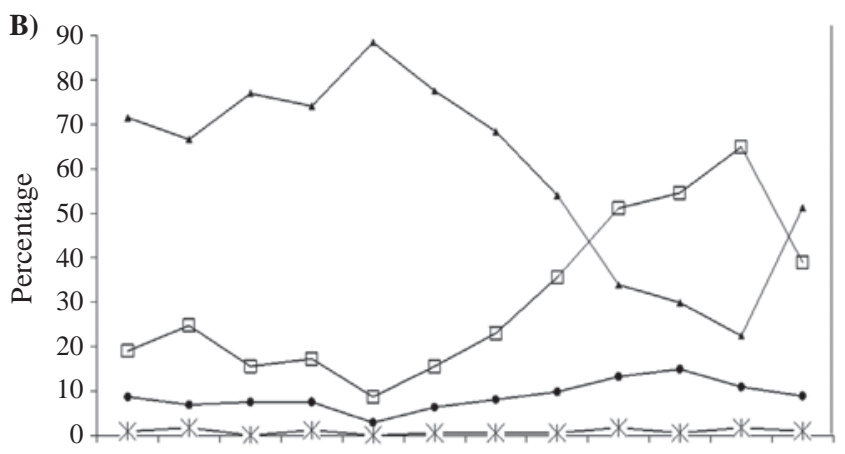

6:00 7:00 8:00 9:00 10:00 11:0012:00 13:00 14:00 15:00 16:00 17:00

Hour

$\star$ Resting $\rightarrow$ Moving $\quad \square$ Feeding $\quad *$ Social

Figure 2. Daily variation in the percentage of records in which red howlers were performing different activities in Meta, Colombia. A) Tinigua and B) Santa Rosa.

\section{Diet and feeding preferences}

Young leaves and fruits were the main components in the diet of both groups. However, individuals in continuous forests consumed fruits in a higher proportion than in the fragment ( $44 \%$ vs. $32 \%, \mathrm{G}=25.7$, df. $=1, \mathrm{p}<0.001$, Figure 1.b). This difference is consistent with the overall fruit production pattern, since the continuous forest showed higher production compared to the fragment (six month estimate: $758.4 \mathrm{~kg} / \mathrm{ha}$ vs. $460.6 \mathrm{~kg} / \mathrm{ha}$, respectively). In the continuous forest, besides leaves and fruits, red howlers were observed ingesting flowers and unripe fruits in low proportions. About $2 \%$ of the total feeding time $(n=828$ min) was spent drinking water, ingesting termitaria and soil from salt licks (a behaviour that is frequent in continuous forests, but not easy to register: Izawa, 1993).

The most consumed fruit species by howlers in continuous forests belong to the Moraceae and Urticaceae families (Table 2), which produce abundant crops. The diet of howlers in the fragment included abundant species (e.g., Protium heptaphyllum, Trattinickia rhoifolia, and Virola elongata) and pioneer species (e.g., Bellucia grossularioides, and Miconia spp.) (Table 2). The diet of the group in the continuous forest included almost three times more fruit species in the diet of the group in the fragment (56 vs. 19). Individuals did not feed from large fruiting trees in the fragment (Figure 4). Fruit consumption was positively correlated with fruit production, since highly productive species were also frequently consumed, particularly in the fragment (Figure 5). However, the predictive power of this relationship was very low for the continuous forest (Figure $5 a$ ). The most preferred species were Protium heptaphyllum in the fragment, and Pseudolmedia hirsuta, Ficus yoponensis, F. insipida, Brosimum utile, B. alicastrum, F. davidsoniae, F. sphenophylla and Celtis schippii in the continuous forest.

Both groups consumed flowers from species belonging to the Bignoniaceae family and some palms (e.g., Mauritia flexuosa -Arecaceae). Seed dispersal was observed for the majority of the consumed ripe fruit species (Stevenson, et al., 2002); however, seed predation was also observed, mainly during periods of food scarcity, when howler monkeys consumed unripe fruits (e.g., Pera arborea -Euphorbiaceae, Brosimum utile-Moraceae). In the continuous forest, Moraceae and Urticaceae were the most consumed plant families in terms of new leaves, including species such as Brosimum alicastrum, B. lactescens, B. utile, Cecropia membranacea, Pseudolmedia laevis, P. laevigata, P. hirsuta, and Ficus insipida. Other important species were Platypodium elegans and Inga spp. -Fabaceae, and Protium sagotianum -Burseraceae. In the fragment, the most important resources for the consumption of young leaves included several pioneer species (e.g., Solanum spp. Cecropia cf. metensis), Bignoniaceae vines, and Erythroxylon sp.

Temporal variations in diet composition were evident in both populations (Figure 6). Monthly fruit consumption tended to be positively correlated with fruit production (continuous: $r^{2}=0.35, \mathrm{n}=13, p=0.03$; fragment: $r^{2}=0.61, \mathrm{n}=6, p=$ $0.06)$. However, the consumption of young leaves was not correlated with production (continuous: $r^{2}=0.00, \mathrm{n}=12, p$ $=0.9$; fragment: $r^{2}=0.53, \mathrm{n}=6, p=0.10$ ). Fruit production was negatively correlated with leaf consumption in the continuous forest: $r=-0.47, F=11.0, \mathrm{n}=13, p=0.01$ ), and a similar trend was obtained for the fragment $(r=-0.59)$, but in the latter the slope of the line was not significantly different from zero $(F=2.2, \mathrm{n}=6, p=0.20)$.

There were few differences in overall feeding composition among age/sex classes and individuals. For example, in the fragment no association was found between the frequency of leaves and fruit consumption, and the different age/sex classes ( $G=0.70, \mathrm{df}=3, p=0.95$ ). Similarly, no differences were found in feeding time among group members in the fragment $(F=1.32, \mathrm{df}=4, p=0.30)$. Even though sampling time varied among individuals in the continuous forest, no significant association was found between diet categories and age/sex classes ( $G=7.6, \mathrm{df}=3, p=0.06)$, suggesting similar traits among individuals. 

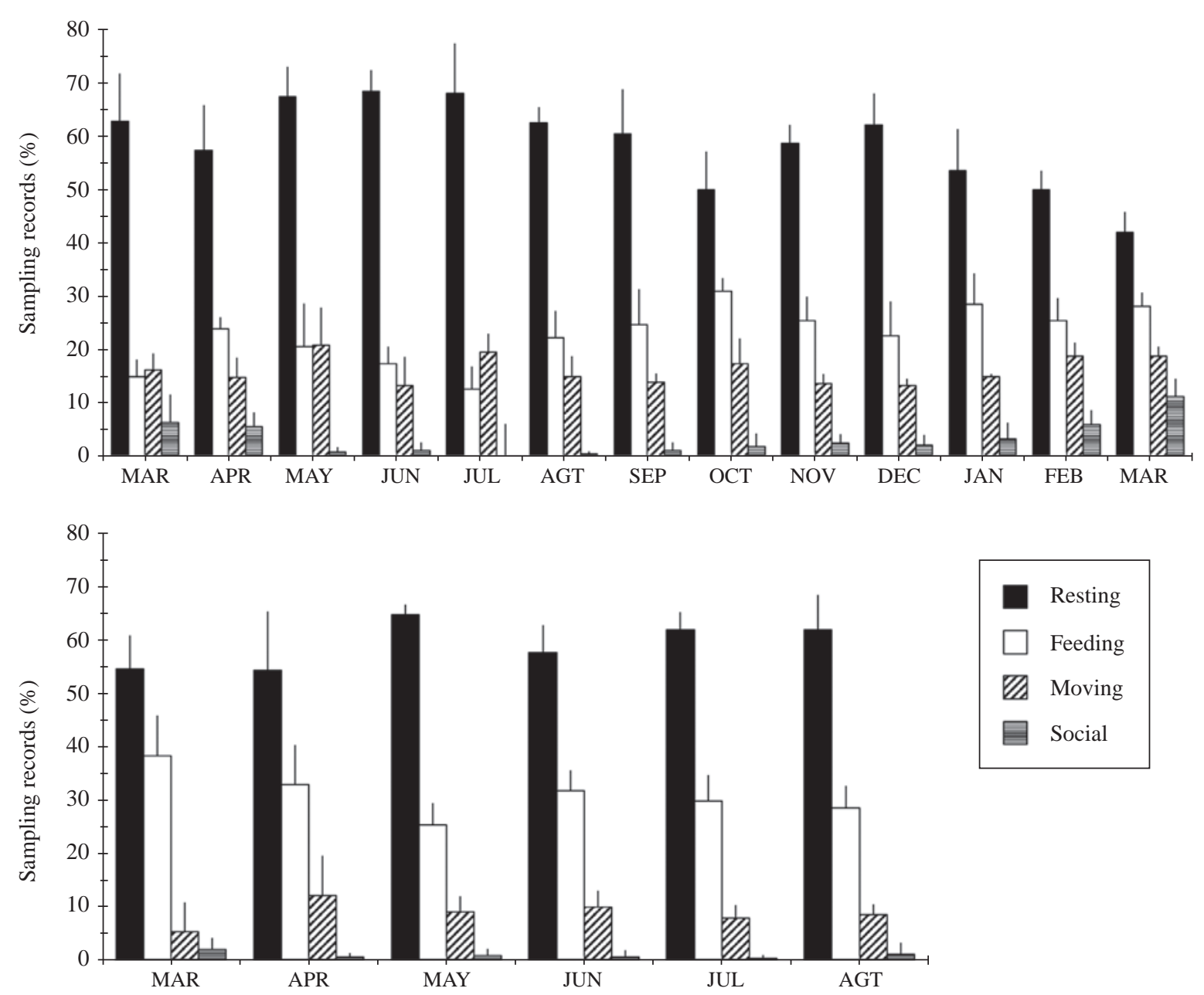

Figure 3. Monthly variation in activity patterns for two populations of red howlers howler monkeys in Meta, Colombia. A) Continuous forest and B) Fragment.

\section{Discussion}

Similar to what has been reported in previous studies comparing the behavior of howler monkeys in pristine and fragmented forests, differences in home range area, activity patterns, and diet were found between groups in continuous and fragmented habitats. For instance, the high density of howler monkeys in fragments has been associated with reduced home range area (Crockett \& Eisenberg, 1987; Palma, et al., 2011). Bravo and Sallenave (2003) suggested the abundance of high quality resources (e.g. associated with soil nutrients) as a factor causing an increase in population density and a reduction in home range size. However, high densities can also occur in fragments with relatively poor soils (Santamaria, 2004). Foliage quality is expected to play a key role explaining howler population densities (Peres, 1997), as it can be a good predictor of the abundance of folivorous primates (Oates, et al., 1990; Ganzhorn, 1992). However this has not been evaluated for Neotropical sites. Howler population densities can also be affected by competition with large frugivorous primates that share a significant proportion of their dietary items (Stevenson, et al., 2000), and that are not common in fragments (Stevenson, 2010).

In spite of the large differences in population density between undisturbed and fragmented sites, few differences were found among group sizes. Howler groups tend to be larger in continuous forests but in both sites group size varies depending on the dynamics of group composition and infanticide (Izawa, 1997). A higher rate of aggression among adult males was observed in the fragment, probably associated to changes in alpha male status. These changes included episodes of infanticide, as expected by the sexual selection hypothesis (van Schaik, 2000), and consistent with the idea that group size may be reduced by infanticide (Sterck, et al., 1997).

Studies on the changes in howler activity patterns associated with fragmentation show variable results (Juan, et al., 2000; Bicca-Marques, 2003; Asensio, et al., 2007). In this comparison, resting was observed in similar proportions in both populations, but movement was 
Table 2. Main plant species contributing to the fruit diet (in terms of feeding time) of two populations of red howler monkeys, differing in fragmentation regimes, in North-Western Amazonia ( $\mathrm{R}=$ ripe, $\mathrm{U}=$ unripe).

\begin{tabular}{|c|c|c|c|c|c|c|c|}
\hline \multicolumn{4}{|c|}{ Continuous forest (Tinigua National Park) } & \multicolumn{4}{|c|}{ Fragment (Santa Rosa farm) } \\
\hline Species & $\begin{array}{l}\text { Feeding } \\
\text { time }(\%)\end{array}$ & Ripeness & Family & Species & $\begin{array}{l}\text { Feeding } \\
\text { time (\%) }\end{array}$ & Ripeness & Family \\
\hline Brosimum alicastrum & $676(20)$ & $\mathrm{R}-\mathrm{U}$ & Moraceae & Trattinickia rhoifolia & $304(22)$ & $\mathrm{R}$ & Burseraceae \\
\hline Ficus davidsoniae & $290(9)$ & $\mathrm{R}$ & Moraceae & Bellucia grossularioides & $284(21)$ & $\mathrm{R}$ & Melastomateceae \\
\hline Pseudolmedia hirsuta & $226(7)$ & $\mathrm{U}$ & Moraceae & Miconia affinis & $197(14)$ & $\mathrm{R}$ & Melastomateceae \\
\hline Ficus coeruescens & 161 (5) & $\mathrm{R}$ & Moraceae & Protium heptaphyllum & $135(10)$ & $\mathrm{R}$ & Burseraceae \\
\hline Ficus sphenophylla & 154 (5) & $\mathrm{R}$ & Moraceae & Miconia multispicata & $79(6)$ & $\mathrm{R}$ & Melastomateceae \\
\hline Castilla ulei & 149 (5) & $\mathrm{R}$ & Moraceae & Miconia sp. & 74 (5) & $\mathrm{R}$ & Melastomataceae \\
\hline Brosimum utile & 148 (5) & $\mathrm{R}-\mathrm{U}$ & Moraceae & Alchorneopsis floribunda & $65(5)$ & $\mathrm{R}$ & Euphorbiaceae \\
\hline Coussapoa orthoneura & 136 (4) & $\mathrm{R}$ & Urticaceae & Virola elongata & 49 (4) & $\mathrm{R}$ & Myristicaceae \\
\hline Pouroma minor & 120 & $\mathrm{R}-\mathrm{U}$ & Urticaceae & Cecropia metensis & 46 (3) & $\mathrm{R}$ & Urticaceae \\
\hline Ficus insipida & 118 (4) & $\mathrm{R}$ & Moraceae & Myrcia sylvatica & 40 (3) & $\mathrm{R}$ & Myrtaceae \\
\hline Gustavia hexapetala & 100 & $\mathrm{R}$ & Lecythidaceae & Virola carinata & 27 (2) & $\mathrm{R}$ & Myristicaceae \\
\hline Celtis schippii & $76 \quad(2)$ & $\mathrm{R}$ & Ulmaceae & Protium glabrescens & $22(2)$ & $\mathrm{R}$ & Burseraceae \\
\hline Pseudolmedia laevigata & $75 \quad(2)$ & $\mathrm{R}$ & Moraceae & Miconia elata & 20 & $\mathrm{R}$ & Melastomataceae \\
\hline
\end{tabular}

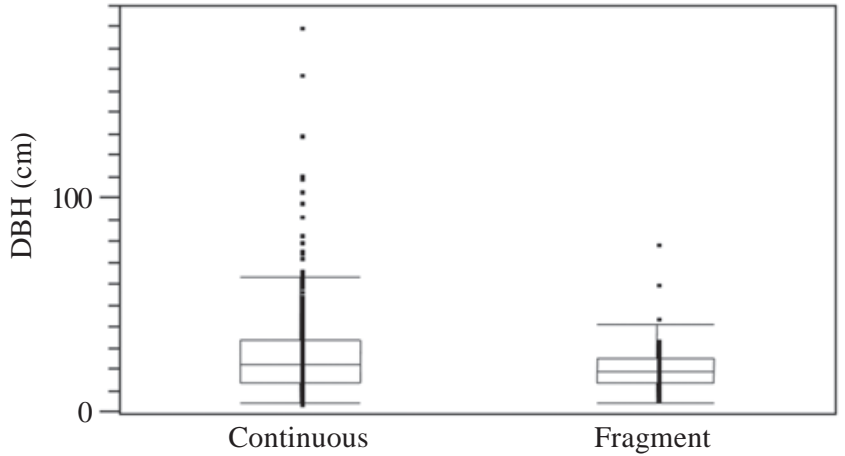

Figure 4. Diameter at breast height (DBH) of fruit resources used by the main study groups.

more frequent in the continuous forest. This may support Milton's ideas (1998) on howler activities being limited by energetic constrains or space limitation. The fact that fruit production was higher in the undisturbed forest seems to explain the higher fruit consumption rates observed in Tinigua Park. Furthermore, the positive relationship between fruit production and social interactions, which require energy (e.g. play), supports the idea that energetic constraints (i.e., fruit intake) may limit some activities (Bravo \& Sallenave, 2003). To compensate for the reduction in fruit availability, commonly associated with fragmentation (Marsh \& Loiselle, 2003; ArroyoRodriguez \& Mandujano, 2006), howler monkey populations might increase feeding time in fragments (Clarke, et al., 2002), and this seems to be the case for the studied group.
Despite the high density of howler monkeys in fragments, differences in the rates of intergroup vocal encounters were not found between study sites. It is possible that high densities may promote group encounters in the fragment, but encounters are more likely when movement is frequent and when home range is large (which may be associated with resource distribution). Therefore, these factors acting together may explain the absence of differences between the sites.

Intragroup agonistic encounters were infrequent, which may be related to energetic or phylogenetic constraints, since other species show higher intra-group agonistic rates (e.g., in continuous forest: Alouatta seniculus: 0.08 per day, Cebus apella: 3.0 per day and Lagothrix lagothricha: 3.9 per day; Stevenson, et al., 2000). Thus, it seems unlikely that migrations of individuals between groups are motivated by competitive intragroup interactions for food. In fact, male migrations are more common in Tinigua Park (Izawa, 1997), probably motivated by reproductive opportunities.

Similar to what has been reported by previous studies (e.g. Cristobal-Azkarate \& Arroyo-Rodriguez, 2007), a high dietary flexibility was observed for the species. In both sites, howler monkeys behaved as generalist fruit consumers, ingesting fruits mainly from abundant species with large crops. Even though howler monkeys are the most folivorous among New World monkeys, fruit production is a good predictor of fruit consumption, while the availability of young leaves does not explain ingestion rates, a pattern observed in both populations. Future studies should assess if the availability of young leaves of preferred species is able to explain their consumption times. 

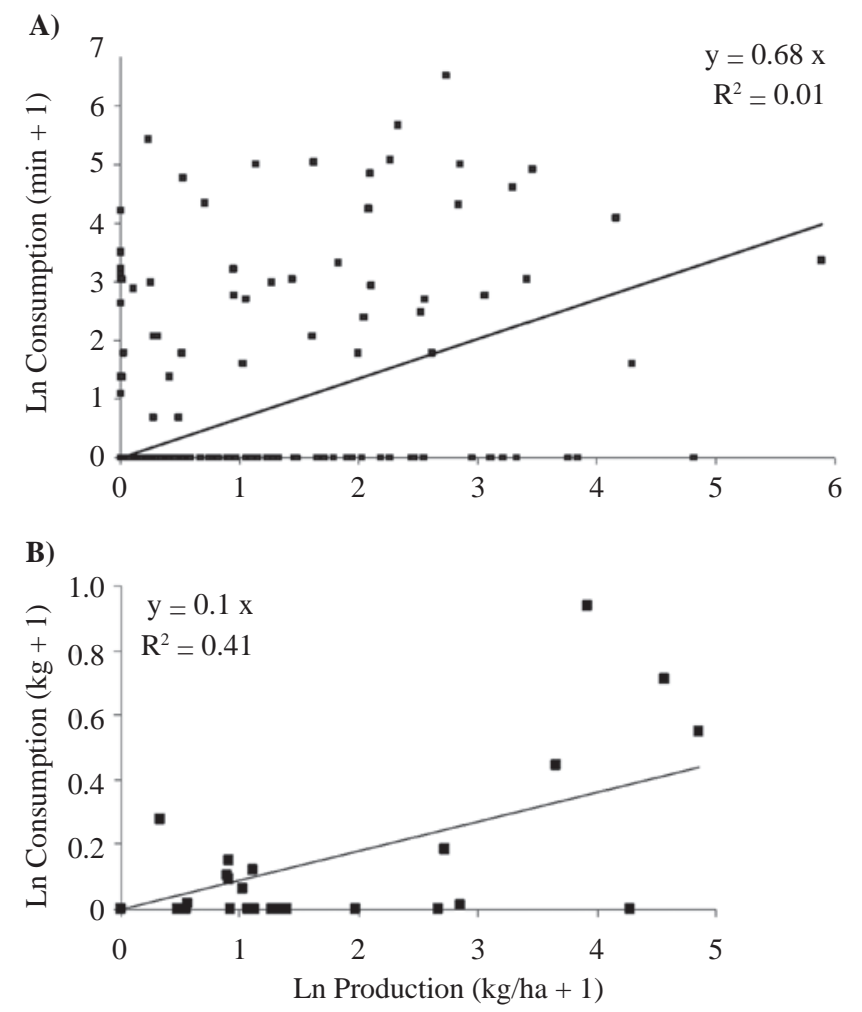

Figure 5. Relationship between fruit production and fruit ingestion in two populations of red howler monkeys in Meta, Colombia: A) Continuous forest and B) Fragment. Each point represents a plant species and fruit consumption in B is expressed as the estimated weight of fruit ingested, while in $\mathrm{A}$ it is shown as visitation time (since it was not possible to have feeding rates and weight for all species).
Overall results from this study suggest that howler monkey populations are able to adapt to different ecological settings, without having to significantly modify their social behavior. Howlers do not seem to be strongly limited by food resources and, thus, populations show low levels of intra and intergroup competition. This leads to an egalitarian society, in which coalitions and linear hierarchies do not affect feeding success, nor dispersal patterns (Isbell \& van Vuren, 1996). Male and female dispersal was observed in both continuous and fragmented forests, a pattern expected when there is low competition for resources. In addition to the known influence of diseases on howler population densities (Rudran \& Fernandez-Duque, 2003), two ecological parameters need to be examined in detail: the nutritional quality of leaves and interspecific competition for fruits.

\section{Acknowledgements}

We thank several anonymous reviewers who made corrections in earlier versions of the manuscript. We thank Drs. Kosei Izawa, Akisato Nishimura, and Koshin Kimura for their help in our first studies of primate ecology. We are very grateful to Familia Sanchez, for the logistic support and for allowing us to carry out the study in Santa Rosa farm, as well as Ana Maria Aldana and Johana Torres for their collaboration during fieldwork. Thomas Defler and Diana C. Guzmán made many useful comments and Diana fixed the final figures. The study in continuous forest was possible thanks to Carlos Mejia, the logistic support of CIEM (Centro de Investigaciones Ecológicas La Macarena),

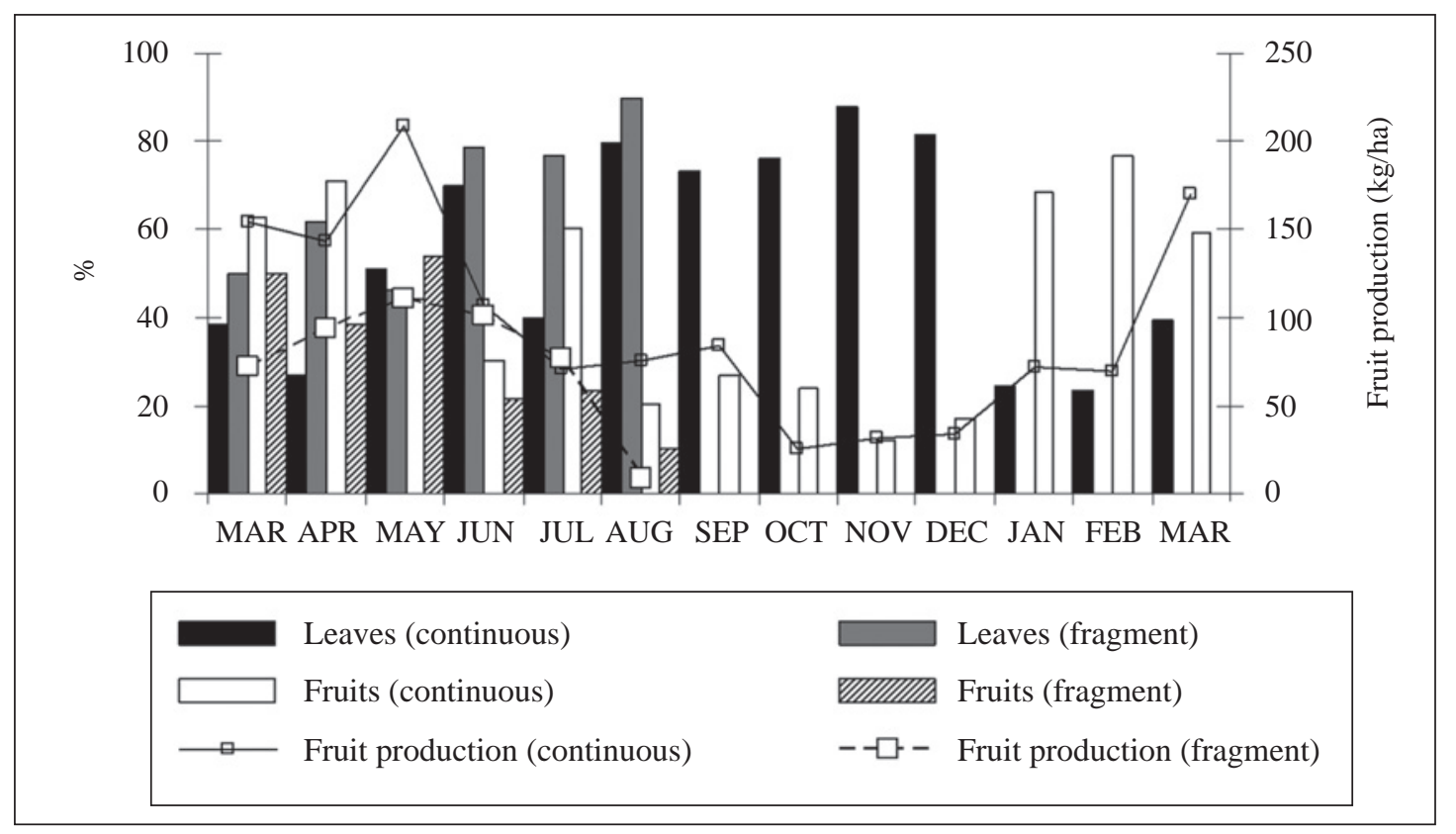

Figure 6. Monthly variation in the proportion of leaves and fruits ingested by two populations of red howler monkeys (continuous forests in Tinigua National Park and a fragment in Santa Rosa farm, Meta, Colombia). The lines represent estimates of ripe fruit production from phenological transects. 
and the permits from Unidad de Parques Nacionales. This study was funded by La Fundación para la Promoción de la Investigación y la Tecnología (Banco de la República).

\section{Conflict of interests}

The authors declares no conflicts of interests.

\section{References}

Agoramoorthy, G., \& Rudran, R. (1993). Male dispersal among free-ranging red howler monkeys (Alouatta seniculus) in Venezuela. Folia Primatologica, 61: 92-96.

Andresen, E. (1999). Seed dispersal by monkeys and the fate of dispersed seeds in a Peruvian rain forest. Biotropica, 31: 145-158.

Arroyo-Rodriguez, V., \& Mandujano, S. (2006). Forest fragmentation modifies habitat quality for Alouatta palliata. International Journal of Primatology, 27: 1079-1096.

Asensio, N., Cristobal-Azkarate J., Dias P.A.D., Vea J.J., \& Rodriguez-Luna, E. (2007). Foraging habits of Alouatta palliata mexicana in three forest fragments. Folia Primatologica, 78: 141-153.

Beltran, M.L., \& Stevenson, P.R. (2012). Twins and infanticide in red howler monkeys inhabiting a fragment in Western Orinoquia. Neotropical Pirmates, 19 (1): 41-42.

Bicca-Marques, J.C. (2003). How do howler monkeys cope with habitat fragmentation? In: L.K. Marsh (ed.) Primates in fragments: Ecology and conservation. (pp. 283-303). Kluwer Academics/Plenum Publishers, New York.

Bravo, S.P., \& Sallenave, A. (2003). Foraging behavior and activity patterns of Alouatta caraya in the northeastern Argentinean flooded forest. International Journal of Primatology, 24: 825-846.

Carretero-P., X. (2008). Efecto de la disponibilidad de recursos sobre la ecología y comportamiento de Saimiri sicureus albigena en fragmentos de bosque de galería, San Martin (Meta- Colombia). MSc thesis. Pontificia Universidad Javeriana, Bogota.

Chapman, C.A., \& Balcomb, S.R. (1998). Population characteristics of howlers: Ecological conditions or group history. International Journal of Primatology, 19: 385-403.

Clarke, M.R., Collins, D.A., \& Zucker, E.L. (2002). Responses to deforestation in a group of mantled howlers (Alouatta palliata) in Costa Rica. International Journal of Primatology, 23: 365-381.

Cristobal-Azkarate, J., \& Arroyo-Rodriguez, V. (2007). Diet and activity pattern of howler monkeys (Alouatta palliata) in Los Tuxtlas, Mexico: Effects of habitat fragmentation and implications for conservation. American Journal of Primatology, 69: 1013-1029.

Crockett, C.M. (1996). The relation between red howler monkey (Alouatta seniculus) troop size and population growth in two habitats. In: M.A. Norconk, A.L. Rosenberger \& P.A. Garber (eds.). Adaptive Radiations of Neotropical Primates. (pp. 489-510). Plenum Press, New York.
Crockett, C.M. (1998). Conservation biology of the genus Alouatta. International Journal of Primatology, 19: 549-578.

Crockett, C.M. (2003). Re-evaluating the sexual selection hypothesis for infanticide by Alouatta males. Special Topics in Primatology, 3: 327-365.

Crockett, C.M., \& Eisenberg, J.F. (1987). Howlers: Variations in group size and demography. In: B.B. Smuts, D.L. Cheney, R.M. Seyfarth, R.W. Wrangham \& T.T. Struhsaker (eds.). Primate Societies. (p. 54-68), University of Chicago Press, Chicago.

Di Fiore, A., \& Campbell, C.J. (2007). The Aletines: Variation in ecology, behavior, and social organization. In: C.J. Campbell, A. Fuentes, K.C. Mackinnon, M. Panger, \& S.K. Bearder (eds.). Primates in Perspective. (pp. 155-185). Oxford University Press; Oxford.

Ganzhorn, J.U. (1992). Leaf chemistry and the biomass of folivorous primates in tropical forests: Test of a hypothesis. Oecologia, 91: 540-547.

Gaulin, S.J.C., \& Gaulin, C.K. (1982). Behavioral ecology of Alouatta seniculus in Andean cloud forest. International Journal of Primatology, 3: 1-32.

Hobbs, R.J., \& Yates, C.J. (2003). Impacts of ecosystem fragmentation on plant populations: generalizing the idiosyncratic. Australian Journal of Botany, 51: 471-488.

Isbell, L.A. (1991). Contest and scramble competition: patterns of female aggression and ranging behavior among primates. Behavioral Ecology, 2: 134-155.

Isbell, L.A., \& van Vuren, D. (1996). Differential costs of locational and social dispersal and their consequences for female group-living primates. Behaviour, 133: 1-36.

Izawa, K. (1993). Soil-eating by Alouatta and Ateles. International Journal of Primatology, 14: 229-242.

Izawa, K. (1997). Social changes within a group of red howler monkeys, VI. Field Studies of Fauna and Flora La Macarena Colombia, 11: 19-34.

Izawa, K., \& Lozano, H. (1992). Social changes within a group of red howler monkeys (Alouatta seniculus) IV. Field Studies of New World Monkeys La Macarena Colombia, 7: 15-27.

Juan, S., Estrada, A., \& Coates-Estrada, R. (2000). Contrastes y similitudes en el uso de recursos y patrón general de actividades en tropas de monos aulladores (Alouatta palliata) en fragmentos de selva en Los Tuxtlas, México. Neotropical Primates, 8: 131-135.

Julliot, C. (1996). Seed dispersal by red howling monkeys (Alouatta seniculus) in the tropical rain forest of French Guiana. International Journal of Primatology, 17: 239-258.

Julliot, C., \& Sabatier, D. (1993). Diet of the red howler monkey (Alouatta seniculus) in French- Guiana. International Journal of Primatology, 14: 527-550.

Kimura, K. (1992). Demographic approach to the social group of wild red howler monkeys (Alouatta seniculus). Field Studies of New World Monkeys La Macarena Colombia, 7: 29-34. 
Laurance, W.F., Lovejoy, T.E., Vasconcelos, H.L., Bruna, E.M., Didham, R.K., Stouffer, P.C., et al. (2002). Ecosystem decay of Amazonian forest fragments: A 22-year investigation. Conservation Biology, 16: 605-618.

Marsh, L.K., \& Loiselle, B.A. (2003). Recruitment of black howler fruit trees in fragmented forests of Northern Belize. International Journal of Primatology, 24: 65-86.

Milton, K. (1998). Physiological ecology of howlers (Alouatta): Energetic and digestive considerations and comparison with the Colobinae. International Journal of Primatology, 19: $513-548$.

Miranda, J.M.D., Bernardi, I.P., Abreu, K.C., \& Passos, F.C. (2005). Predation on Alouatta guariba clamitans Cabrera (Primates, Atelidae) by Leopardus pardalis (Linnaeus) (Carnivora, Felidae). Revista Brasileira de Zoologia, 22: 793-795

Oates, J.F., Whitesides, G.H., Davies, A.G., Waterman, P.G., Green, S.M., Dasilva, G.L., \& Mole, S. (1990). Determinants of variation in tropical forest primate biomass - new evidence from West-Africa. Ecology, 71: 328-343.

Palma, A.C., Vélez, A., Gómez-Posada, C., López, H., ZárateCaicedo, D. A., \& Stevenson, P.R. (2011). Use of space, activity patterns, and foraging behavior of red howler monkeys (Alouatta seniculus) in an Andean forest fragment in Colombia. American Journal of Primatology, 73 (10), 1062-1071.

Peres, C.A. (1997). Effects of habitat quality and hunting pressure on arboreal folivore densities in Neotropical forests: A case study of howler monkeys (Alouatta spp.). Folia Primatologica, 68: 199-222.

Pope, T.R. (1990). The reproductive consequences of male cooperation in the red howler monkey: paternity exclusion in multimale and single-male troops using genetic markers. Behavioral Ecology and Sociobiology, 27: 439-446.

Pope, T.R. (1992). The Influence of dispersal patterns and mating system on genetic differentiation within and between populations of the red howler monkey (Alouatta seniculus). Evolution, 46: 1112-1128.

Rudran, R., \& Fernandez-Duque, E. (2003). Demographic changes over thirty years in a red howler population in Venezuela. International Journal of Primatology, 24: 925-947.

Sallis, E.S.V., de Barros, V., Garmatz, S.L., Fighera, R.A., \& Graca, D.L. (2003). A case of yellow fever in a brown howler (Alouatta fusca) in Southern Brazil. Journal of Veterinary Diagnostic Investigation, 15: 574-576.

Santamaría, M. (2004). The effect of home range reduction on the ecology of red howler monkeys in Central Amazonia. Doctoral thesis, University of Cambridge. Cambridge, UK.

Santamaría, M., \& Rylands, A.B. (2003). Ecología básica de un grupo de Alouatta seniculus durante la estación seca en la Amazonia central brasilera. In: V. Pereira-Bengoa, F. Nassar-Montoya \& A. Savage (eds.). Primatologia del Nuevo Mundo: Biología, medicina y conservación. (pp. 96111). Centro de Primatologia Araguatos, Bogotá.
Saunders, D.A., Hobbs, R.J., \& Margules, C.R. (1991). Biological consequences of ecosystem fragmentation: A review. Conservation Biology, 5: 18-32.

Sekulic, R. (1982). The function of howling in red howler monkeys (Alouatta seniculus). Behaviour, 81: 38-54.

Sterck, E.H.M., Watts, D.P., \& van Schaik, C.P. (1997). The evolution of female social relationships in nonhuman primates. Behavioral Ecology \& Sociobiology, 41: 291-309.

Stevenson, P.R. (2007). Estimates of the number of seeds dispersed by a population of primates in a lowland forest in western Amazonia. In: A.J. Dennis, E.W. Schupp, R.J. Green \& D.W. Westcott (eds.). Seed dispersal: theory and its application in a changing world. (pp. 340-362). CAB International, Wallingford, UK.

Stevenson, P.R. (2010). Efectos de la fragmentación y de la producción de frutos en comunidades de primates Neotropicales. In: V. Pereira-Bengoa, P.R. Stevenson, M.L. Bueno \& F. Nassar (eds.). Avances en la Primatología del Nuevo Mundo. (pp. 239-257). Centro de Primatología Araguatos, Bogotá.

Stevenson, P.R., \& Aldana, A.M. (2008). Potential effects of ateline extinction and forest fragmentation on plant diversity and composition in the Western Orinoco basin, Colombia. International Journal of Primatology, 29: 365-377.

Stevenson, P.R., Castellanos, M.C., Cortes, A.I., \& Link, A. (2008). Flowering patterns in a seasonal tropical lowland forest in western Amazonia. Biotropica, 40: 559-567.

Stevenson, P.R., Castellanos, M.C., Pizarro, J.C., \& Garavito, M. (2002). Effects of seed dispersal by three ateline monkey species on seed germination at Tinigua National Park, Colombia. International Journal of Primatology, 23: 1187-1204.

Stevenson, P.R., \& Link, A. (2010). Fruit preferences of Ateles belzebuth in Tinigua Park, Northwestern Amazonia. International Journal of Primatology, 31: 393-407.

Stevenson, P.R., Quiñones, M.J., \& Ahumada, J.A. (1998). Effects of fruit patch availability on feeding subgroup size and spacing patterns in four primate species at Tinigua National Park, Colombia. International Journal of Primatology, 19: 313-324.

Stevenson, P.R., Quiñones, M.J., \& Ahumada, J.A. (2000). Influence of fruit availability on ecological overlap among four Neotropical primates at Tinigua National Park, Colombia. Biotropica, 32: 533-544.

Stevenson, P.R., Suescún, M., \& Quiñones, M.J. (2004). Characterization of forest types at the CIEM, Tinigua Park, Colombia. Field Studies of New World Monkeys La Macarena Colombia, 14: 1-19.

Terborgh, J., \& Janson, C.H. (1986). The socioecology of primate groups. Annual Review of Ecology \& Systematics, 17: 111-135.

Thorington, R.W.J., Rudran, R., \& Mack, D. (1979). Sexual dimorphism of Alouatta seniculus and observations on capture techniques. In: J.F. Eisenberg (ed.). Vertebrate 
Ecology in the Northern Neotropics. (pp. 97-106). Smithsonian Institution Press, Washington D. C., USA.

Torres-Neira, J.A. (2005). Historia natural de Cebus apella y patrones de asociación interespecífica con Saimiri sciureus en un bosque fragmentado (Meta, Colombia). B.Sc thesis. Universidad de Los Andes, Bogotá.

Treves, A., Drescher, A., \& Ingrisano, N. (2001). Vigilance and aggregation in black howler monkeys (Alouatta pigra). Behavioral Ecology \& Sociobiology, 50: 90-95. van Schaik, C. (2000). Infanticide by male primates: the sexual selection hypothesis revisited. In: C. van Schaik \& C.H. Janson (eds.). Infanticide by males and its implications. (pp. 27-60). Cambridge University Press, Cambridge, UK.

Wang, E., \& Milton, K. (2003). Intragroup social relationships of male Alouatta palliata on Barro Colorado Island, Republic of Panama. International Journal of Primatology, 24: 1227-1243. 